\title{
Explaining Birds' Sexual Selection and Colorful Plumages by Food and Environment Demands
}

\author{
Chenguang Lu* \\ College of Intelligence Engineering and Mathematics, China
}

Submission: May 09, 2018; Published: May 22, 2018

*Corresponding author: Chenguang Lu, College of Intelligence Engineering and Mathematics, Liaoning Engineering and Technology University, Fuxin, Liaoning, 123000, China, Email: Survival99@gmail.com

\begin{abstract}
Why do many male birds display specific colorful patterns on their plumages? The demand-relationship theory explains that beauty preferences reflect human and birds' desire for approaching some objects, which resemble their ideal food sources or environments. Mutants that have enhanced human and birds' ability and motivation in finding these were hence selected by nature. Such beauty preferences of the female birds then selected the male plumage.
\end{abstract}

Keywords: Beauty preferences; Sexual selection; Demand-relationship theory; Colorful plumages; Evolution

\section{Introduction}

\section{Contradiction between Darwin and Wallace}

Darwin [1] explains that fragrance and colorfulness of flowers are to attract insects to pollinate for them; good flavor and colorfulness of fruits are to attract birds and mammals to swallow to spread their seeds. However, Darwin was puzzled by why insects, birds and mammals had such tastes [1], Ch. 6, Sec. 8). Later, Darwin advanced sexual selection to explain the colorful appearances of male birds [2]. Wallace objected strongly $[3,4]$, saying that this is adding an additional principle of beauty selection on top of natural selection, without explaining where female taste for beauty comes from. Wallace used camouflage and signaling to explain colorful plumages in birds, used good sense or sign to explain female sexual selection, while denying the selection of male appearance by the taste for beauty of the female birds. There are also some other explanations [5].

We proposed a demand-relationship theory for the evolution of tastes [6-8]. The evolution of demand observes the rule of means turning into ends $[7,8]$. For example, fishing was the means for eating fish, but it has become an end in itself. The author is not alone. Lately Merle E Jacobs [9] also proposed that the peacock mimicked berries. Rodd [10] found that guppies had orange round spots on their tails for mimicking their favorite foods. This finding obtained very high praise by a paper on Science [11].

\section{Using food sources and environments to explain birds' colorful plumages}

Why does the plumage of Peacocks contain the distinctive ocelli in their tails? Peafowls like to eat berries ${ }^{1}$. This first led to them to find berries beautiful. This beauty preference of peahens then selected for the ocelli in the tails of peacocks so that a peacock displays the tail that looks like a berry tree (see Figure 1). Similarly, many birds such as Beautiful Fruit Dove have red spots on top of their heads that clearly mimic ripe fruits ${ }^{2}$ that those birds like to eat; a parrot may have a mango-like head ${ }^{3}$. We can also find some birds with flowers on head, such as Kinglet and Goldcrest. These birds must like flowers for eating nectar. Most species of humming birds display flower-like colors and patterns on their necks ${ }^{4}$ because humming birds likes flowers. The Rainbow Lorikeet ${ }^{5}$ feeds mainly on fruit, pollen and nectar, it also has multicolored plumage. Also, many birds display patterns of grain ears in their plumages because they like to eat these grains, such as Chrysolophus, Montezuma Quail, Zebra Finch, and House Cock. There are also many bird species with plumages resembling insects that they like to eat. For example, the Sunbittern has plumage mimicking butterflies and moths.

\footnotetext{
${ }^{1}$ http://survivor99.com/lcg/english/beauty/birds-beauty.pdf

${ }^{2}$ http://image.sciencenet.cn/album/201403/04/1433269mizdbrrxwb1dmoq.jpg

${ }^{3}$ http://blog.sciencenet.cn $/$ home.php? mod=space\&uid=2056\&do=album\&picid=422991

${ }^{4} \mathrm{http} / / /$ blog.sciencenet.cn/home.php? $\mathrm{mod}=$ space\&uid=2056\&do=album\&picid $=422990$

${ }^{5}$ http://blog.sciencenet.cn/home.php? mod=space\&uid=2056\&do=album\&picid=601203
} 


\section{Current Trends in Biomedical Engineering \& Biosciences}

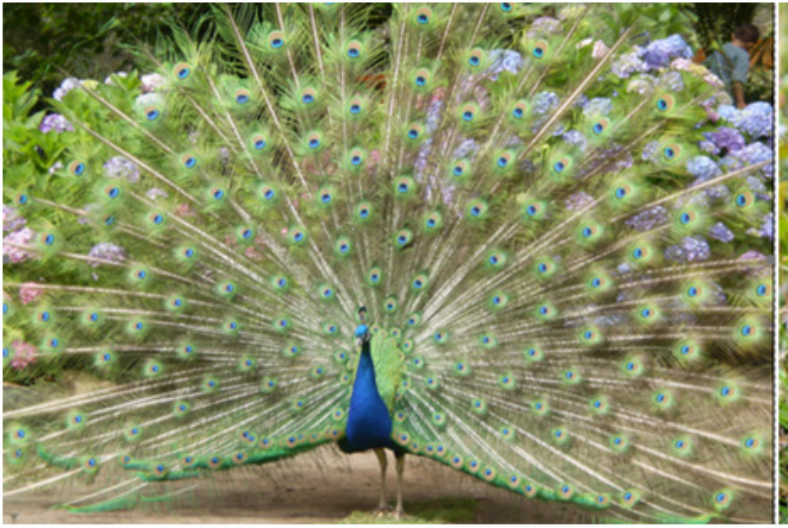

(a)

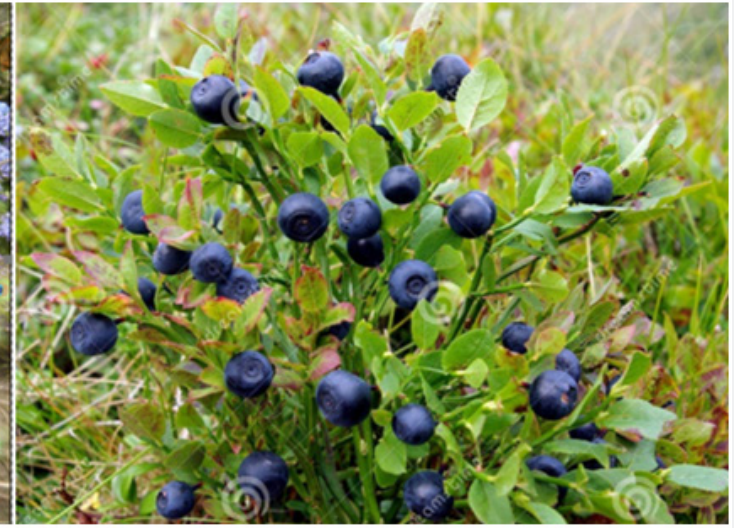

(b)

Figure 1: A Peacock (a) (Thanks to Jean Rogers ${ }^{1}$ ) and a wild blueberry tree (b) (Thanks to Shargaljut ${ }^{2}$ ).

We can also find some birds mimicking ant colonies or ant eggs, such as Brown Thrasher6, Wood Thrush, Ovenbird, and Rusty-backed Antwren. They either like eating ants (or ant eggs), bathing with ants, or following army ants to find insects for food. Many birds living in water mimic water-related food sources. For example, male Mandarin Duck has wings and yellow plumage that mimic a clam with stretching flesh ${ }^{7}$; male Wood Duck has wings looking like shellfish and head looking likes a snail $^{8}$. Male King Eider also has a head looking like a snail ${ }^{9}$. The
Tufted Puffin has a head looking like a prawn. This bird must like to catch and eat prawns ${ }^{10}$.

Though the plumage of Macaws is beautiful to us, the claylike patterns on their faces look ugly ${ }^{11}$. Why? To dispense with the poison contained in the leaves that they eat, Macaws also eat clay. This demand for clay makes them find clay beautiful and the appearance of clay-like spots on their face got selected. Similarly, as the King Vulture likes to feed on dead bodies of large animals, male King Vultures displays torn fur and uncovered flesh.

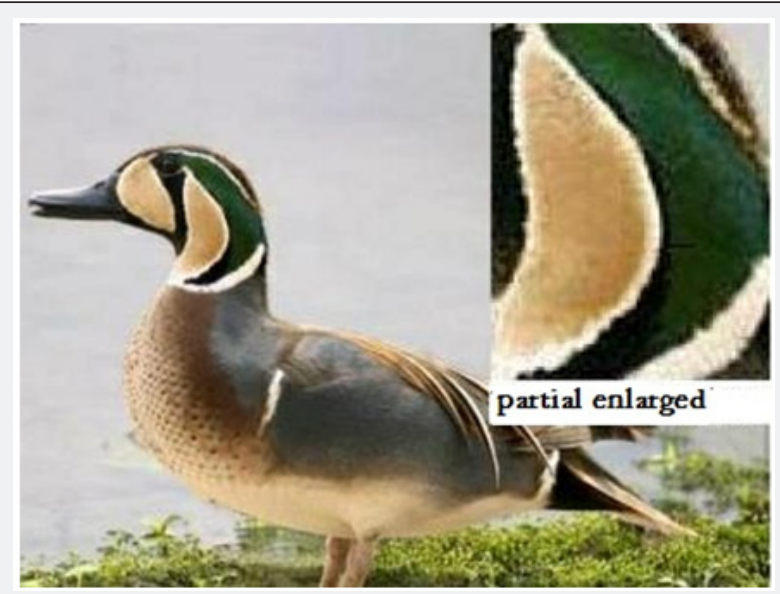

Figure 2: A male baikal teal displays alluvions on a river. Thanks to lool for his kind permission?3.

Many species of ducks have, on their plumages, blue or green pattern mimicking deep water, wavy pattern mimicking shallow water, and brown pattern mimicking wetland. For example, the
Green Winged Teal have each of these patterns. The Baikal Teal has more delicate island-like pattern (Figure 2). In the winter, Baikal Teals fly to the Yangtze river basin. Sand islands or

\footnotetext{
${ }^{1}$ This image is licence free from https://ccsearch.creativecommons.org/image/detail/uA0Qy6et0Dx6WWp99i5jFQ

${ }^{2}$ This is a royalty free image from https://www.dreamstime.com/royalty-free-stock-photos-blueberry-bush-image11589318 ${ }^{3}$ http://www.cnbird.org.cn/ (search "Baikal Teal" can find the creator Lool and his works)

${ }^{6}$ https://en.wikipedia.org/wiki/Brown_thrasher

${ }^{7}$ http://blog.sciencenet.cn/home.php? $\bmod =$ space\&uid=2056\&do=album\&picid=8515

${ }^{8}$ http://blog.sciencenet.cn/home.php?mod=space\&uid=2056\&do=album\&picid=8513

${ }^{9}$ http://blog.sciencenet.cn/home.php?mod=space\&uid=2056\&do=blog\&id=742139

${ }^{10} \mathrm{http}: / /$ stock.chrisdoddsphoto.com/famain.asp?customerId=112\&sKey=GHCSEHNJ\&action=viewimage\&cid=76\&image ${ }^{\text {id }=283}$

${ }^{11} \mathrm{http}: / /$ blog.sciencenet.cn/home.php?mod=space\&uid=2056\&do=album\&picid=410907
} 
alluvions in the river are their most favored spots for feeding and resting (being away from predators). The mimicking of alluvions on their faces is very impressive. Note there are green color for river, yellow color for alluvions, black color for river bank, and white color for spoondrift. Similarly, the Egyptian Plover, which breeds on sandbars or allucions in very large rivers, also displays river and alluvion ${ }^{12}$.

\section{Conclusion}

We have provided ultimate explanations for the origin of particular beauty preferences. This demand-relationship theory may be subject to rigorous test. We have tested many predictions, according to bird's appearances, such as the Baikal Teal and the Egyptian plover's liking alluvions in rivers, the Sunbittern's liking eating butterflies, the King Eider's liking eating snails, the Macaw's liking eating clay ${ }^{13}$. We also used statistical data to test the hypothesis "If a bird has yellow feather then it probably likes eating nectar". The confirmation measure is $0.96^{14}$. In comparison with existing theories [5], the demand-relationship theory can explain birds' sexual selection better.

\section{References}

1. Darwin C (1959) On the origin of species by means of natural selection. John Murray, New York, USA.
2. Darwin C (1871) The Descent of man, and selection in relation to sex. John Murray, New York, USA.

3. Wallace AR (1871) Review of darwin's descent of man. The Academy (2): $177-183$

4. Wallace AR (1897) Notes on natural selection. Natural Science (1): 749-740.

5. Cronin H (1991) The ant and the peacock. Cambridge University Press, London.

6. Lu C (1987) Trying to resolve the problem left by darwin about fragrance, sweetness and beauty. Information from Nature (in Chinese), pp. 25-27.

7. Lu C (1989) On beauty as feedback signal of stirring loving mood (in Chinese). Journal of Changsha University, 3: 56-60.

8. Lu C (2003) The mystery of beauty taste and the evolution of needs (in Chinese). China Science and Technology University Press, Hefei, China.

9. Jacobs ME (1998) Darwin misread miss peacock's mind: a new look at mate selection in light of lessons from nature. Nature Books, Victoria.

10. Rodd FH, Hughes KA, Grether G, Baril CT (2002) A possible non-sexual origin of a mate preference: are male guppies mimicking fruit? Proc $\mathrm{R}$ Soc B 269: 475-481.

11. Morell V (2002) Guppy sex and gluttony guided by orange glow. Science 295(5561): 1816-1817.

\begin{tabular}{l} 
Your next submission with Juniper Publishers \\
will reach you the below assets \\
- Quality Editorial service \\
- Swift Peer Review \\
- Reprints availability \\
- E-prints Service \\
- Manuscript Podcast for convenient understanding \\
- Global attainment for your research \\
- Manuscript accessibility in different formats \\
( Pdf, E-pub, Full Text, Audio) \\
- Unceasing customer service \\
Track the below URL for one-step submission \\
https://juniperpublishers.com/online-submission.php \\
\hline
\end{tabular}

\footnotetext{
${ }^{12} \mathrm{http} / / /$ en.wikipedia.org/wiki/Egyptian_Plover

${ }^{13}$ http://blog.sciencenet.cn/home.php?mod=space\&uid=2056\&do=album\&id=23161

${ }^{14} \mathrm{http}: / /$ survivor99.com/lcg/english/beauty/birds-beauty.pdf
} 